\title{
HOLACRACY AS A NEW APPROACH TO NEW PRODUCT DEVELOPMENT IN IT INDUSTRY - CASE STUDY
}

\author{
Filip LIEBERT \\ Silesian University of Technology, Faculty of Organization and Management; filip.liebert@polsl.p1 \\ ORCID: 0000-0001-8700-2604
}

Purpose: The main objective of this paper was to identify and determine the potential of holacracy from the point of view of new product development in the IT industry.

Design/methodology/approach: The article contains a literature review on the subject of holacracy and a detailed case study analysis conducted in two IT companies which concerned the new product development process. Also, the article presents research results of a quantitative survey and results of interviews with employees that revealed key attributes of teams working in holacracy.

Findings: Research results indicate that companies tend to adapt and adjust holacracy in a unique way to meet their development needs, but such approach requires a specific organizational culture and high-tech resources. Holacracy can enhance NPD process and induce self-development among holacratic development teams, which have a dozen of unique attributes in comparison to traditional teams. Agile development with holacracy is faster and more effective than standard agile development or waterfall approach.

Research limitations/implications: The research results presented in the paper were based only on two IT companies which use new approaches to new product development. Therefore, more scientific research should be carried out in the future to discuss this topic further.

Practical implications: The author of the article recommends that every company should evaluate its capabilities, organizational culture and technical resources before implementing holacracy.

Originality/value: This paper presents and discusses a brand new approach to new product development used by modern IT companies. Holacracy is still considered as a new and innovative approach to managing organizations.

Keywords: NPD, holacracy, teal organizations, project management, IT products.

Category of the paper: Research paper, case study. 


\section{Introduction}

In a fast-growing economy, companies have to launch more sophisticated products to meet the needs of consumers and struggle with constant increase of competition. In particular, this applies to Information Technology (IT) sector, where IT companies develop modern software solutions or release new innovative hardware on the market according to strictly defined customer requirements (Liebert, 2017). The new product development (NPD) in IT companies is based mainly on agile methods (Highsmith, 2015), such as Scrum, in which the final user (also known as Product Owner) actively participates in the development process. Agile methods have many unique advantages like high efficiency of workflow and high flexibility of project's scope (Ellis, 2016).

Literature indicates that the innovativeness of new products often depends on the unique features or attributes of enterprises and their relations with competitive environment (Gopalakrishnan, Damanpour, 1997). Unique capabilities of companies specializing in a particular industry enable them to effectively implement new products in dynamic environment (Griffin, 1998). The aforementioned features of companies which specialize in a specific class of industry usually are identified as: innovation strategies (Januszak, et al., 2002), resources and competences (Danielak, 2010), internal management systems and methods, as well as relationships with the environment (Stabryła, Małkus, 2012). The approach to NPD and the way the development team is organized are also very important factors. IT products in the form of modern software must have a number of unique attributes in order to be described as innovative (Liebert, 2018). These attributes include: innovative features and usability (product functions), customized product functionality, online compatibility with various cloud services, and intelligent adaptation to user's activities.

This scientific paper identifies the potential of holacracy from the point of view of new product development process. The article contains a literature review on the topic of holacracy and a detailed case study analysis that was conducted in two Polish IT companies - the case study concerned the impact of holacracy on NPD process. The article presents research results of a quantitative survey which indicates that holacracy combined with agile methods can be much more effective than other NPD approaches used in IT industry. Also, the results of interviews with employees working in both analyzed companies provided valuable information that revealed key attributes of teams working in holacracy. The conducted researched allowed to identify the key advantages and disadvantages of holacracy from the perspective of new IT product development. All findings of this study imply that implementation of holacracy may be a very difficult and demanding task. 


\section{Holacracy definition and concept of teal management}

\subsection{The idea of turquoise management and search for new solutions}

There are many reasons to search for new solutions in the area of product development team organization. According to Frederic Laloux, author of Reinventing Organizations (Laloux, 2014), people have exceeded a certain level of personal and organizational awareness. This is a very positive trend, because the so-called red organizations, full of formalized rules and strict regulations, are moving towards teal organizations in which relations, freedom of creation and values, are slowly becoming their main principles. Teal (or turquoise) color is a symbol of the highly developed consciousness level of a particular employee and overall awareness of an organization. In other words, if an employee reaches this level of awareness, he or she becomes an individual who wants to work in an environment set towards further expansion, self-development and passion. Such worker wants to be flexible, get to know various tasks and exchange them with other people. Salary or financial benefits don't play the main role in such a case - but personal fulfilment, authenticity and honesty. This approach guarantees a fast pace of changes and a great flexibility, which leads to efficiency. This approach works well in creative industries (Olesiński, 2018). In addition, unlike red, amber, orange and green organizations (the quoted colors can be considered as a scale range - from the most authoritarian to the most democratic and tolerant system), teal organizations focus on collaboration, networking and feedback. They can take the form of strategic coopetitions, as well as internal, ad-hoc temporary collaboration networks in which experts with specific roles complement each other depending on the tasks that have to be carried out. The dimension of empowerment in teal organizations is extremely high, which is a complete opposite of the previous approaches where subordinates were taking orders and objectives from a top-down managerial perspective. Modern companies try to develop their skills in the areas of swift communication, agility and flexibility. Purpose-drivenness and self-drivenness are the new underlying principles, especially in IT companies (Coughlan, College, 2016). Teal organization is being defined by most scientists as advancing towards the highest level of organizational evolution, which ensures stable and comprehensive new product development opportunities for the company. One of the key and fundamental elements of teal management is knowledge. Thanks to efficient knowledge sharing, triggering creativity, limiting supervision over employees, empowerment, flexible structure and, above all, treating each employee as a co-author of each product (and not as before - an employee in the form of a resource or tool), enterprises evolve dynamically from the organizational perspective (Powichrowska, 2018). An additional advantage of the teal approach is the support of soft aspects (that is, sociological and psychological factors) when solving conflicts and disputes in teams (Kozina, Pieczonka, 2018). Despite many advantages, there are also some limitations. First of all, despite the lack of hierarchy in the organizational structure in teal company (one of the principles of team 
management approach), there will always be some forms of hierarchy levels (TomaszyckaHopej, Hopej, 2018). Regardless of whether it is a network or a holacracy, a certain hierarchy will always remain (for example, the relationship between a circle and a sub-circle). In addition, there are some adaptation problems associated with organizational culture and social aspects when enterprises try to implement this type of management model. Operational rules of individual, self-organizing workstations require proper adjustment of organization's internal management systems, which is often quite a complex task. Holacracy is one of the approaches that follows the path of teal management - it has been discussed and analyzed in the following chapters.

\subsection{The main principles of holacracy and its potential for organizational development}

Holacracy is a new purpose-driven approach for managing organizations that replaces the conventional management hierarchy with decentralized self-management, supports self-organizing teams and allows employees to work in an environment where they share the equal amount of authority (Robertson, 2015a). Robertson B.J. is one of the authors of holacracy concept and the organizational model based on this approach, who in 2011 released a Manifesto of Holacracy (the current version of the Holacracy guidebook was published in May, 2015). The manifesto contains key guidelines and principles for enterprises which would like to use this concept of organizational model. As the author states, the manifesto should be treated as a guideline for further action, and not as a methodology containing a specific procedure. This is a rather new concept, which has become more popular in the last few years (Ziębicki, 2017). As the Holacracy Constitution states, the whole concept is based on five key components ${ }^{1}$. These are the following:

1. Energizing roles.

2. Circle structure.

3. Governance process.

4. Operational process.

5. Adoption matters.

There are two primary constructs of holacracy - circles and roles. A circle, in accordance to the guidelines of holacracy constitution, means a fundamental structural unit which has a specific role. Each role has unique domains, specific purpose and accountabilities. Unique domains can be defined as level of role's empowerment in decision-making and overall control of specific activities. Specific purpose is a goal, capacity and potential that the role is going to pursue on behalf of the organization. Accountabilities can be understood as responsibilities associated with the ongoing activities in the organization. Circles can consist of smaller sub-circles which include a set of various roles required to perform a specific task or objective. Another interesting feature of roles within a circle is their self-organization and integrated

\footnotetext{
${ }^{1}$ Official HolacracyOne website: https://www.holacracy.org/constitution.
} 
decision-making. Each circle or sub-circle consists of circle members - employees with different skills and abilities. In other words, every employee has his or her own specific role in the company. Various unexpected roles have often suddenly emerged during the software development projects executed in IT industry. As the author of this concept describes there were some cases in IT companies when a programmer had to perform additional work in the field of, for example, software testing or even contribute to some tasks associated with marketing or computer graphics (Robertson, 2015b). Apart from the usual development roles there are also the so-called 'core-roles' (such as Facilitator, Secretary, Lead Link, and Rep Link) which govern the workflow and rules of a particular circle.
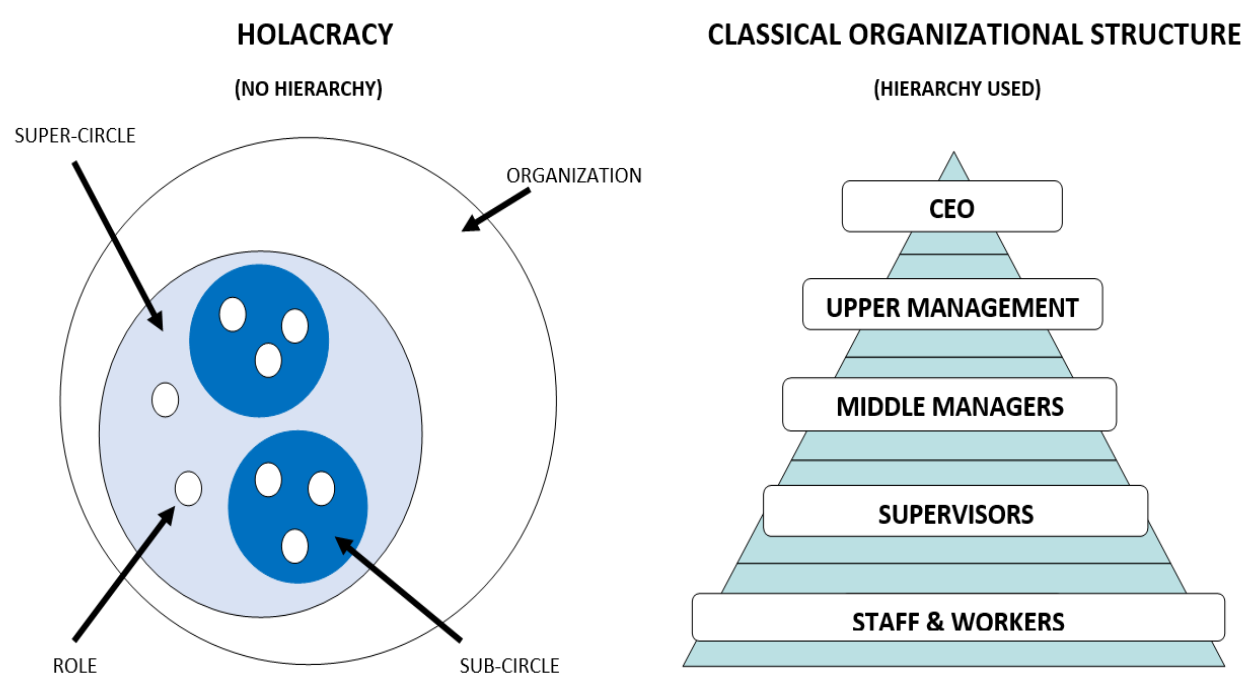

Figure 1. Comparison of holacracy and classical organizational structure. Source: own work based on Robertson B. J.: Holacracy: The New Management System for a Rapidly Changing World. Henry Holt and Company. 2015.

In addition to mentioned circles, sub-circles and roles, there are also super-circles (referred in the Holacracy constitution as Anchor Circles). These huge structural elements of holacracy are usually related to the core business of the company or may even represent an organization as a whole. With so many superior and subordinate forms, this type of structure can be dynamically changed and adapted to the current needs of the organization (Van de Kamp, 2014). As a result, the number of circles and roles can be adapted to the currently ongoing projects or economic activities of the enterprise. A comparison of the holacratic structure with the classical structure (with top-down hierarchy and decision-making levels) is shown in Figure 1.

For a better understanding of how holacracy actually works, it's worth to examine the official Holacracy Quickstart Guide. The guide contains seven key steps that need to be followed and analyzed during the implementation of holacracy approach in an enterprise ${ }^{2}$ :

\footnotetext{
${ }^{2}$ Holacracy Quickstart Guide v. 2.3a - available online on 03.03.2019: http://www.holacracy.org/wp-content/ uploads/2015/05/holacracy_quickstart_guide_v2.3a.pdf.
} 
1. Determine if You Truly Have an Organization.

2. Formally Adopt the Holacracy Constitution.

3. Set up a Shared System for Governance Records.

4. Determine an Initial Structure.

5. Hold First Governance Meetings \& Run Elections.

6. Set up a Shared "Corkboard" for Operational Items.

7. Start Tactical Meetings.

As can be seen from the above description, the implementation of holacracy is a rather difficult and complicated process, especially when the company doesn't show any desire to adopt empowered and self-organizing forms of work. Therefore, a proper strategy has to be executed and some forecasts have to be made in order to check how the company is going to prevail if it successfully passes through all steps of implementation process. Figure 2 shows an overview of an IT company (involved in software development) using the holacracy concept.

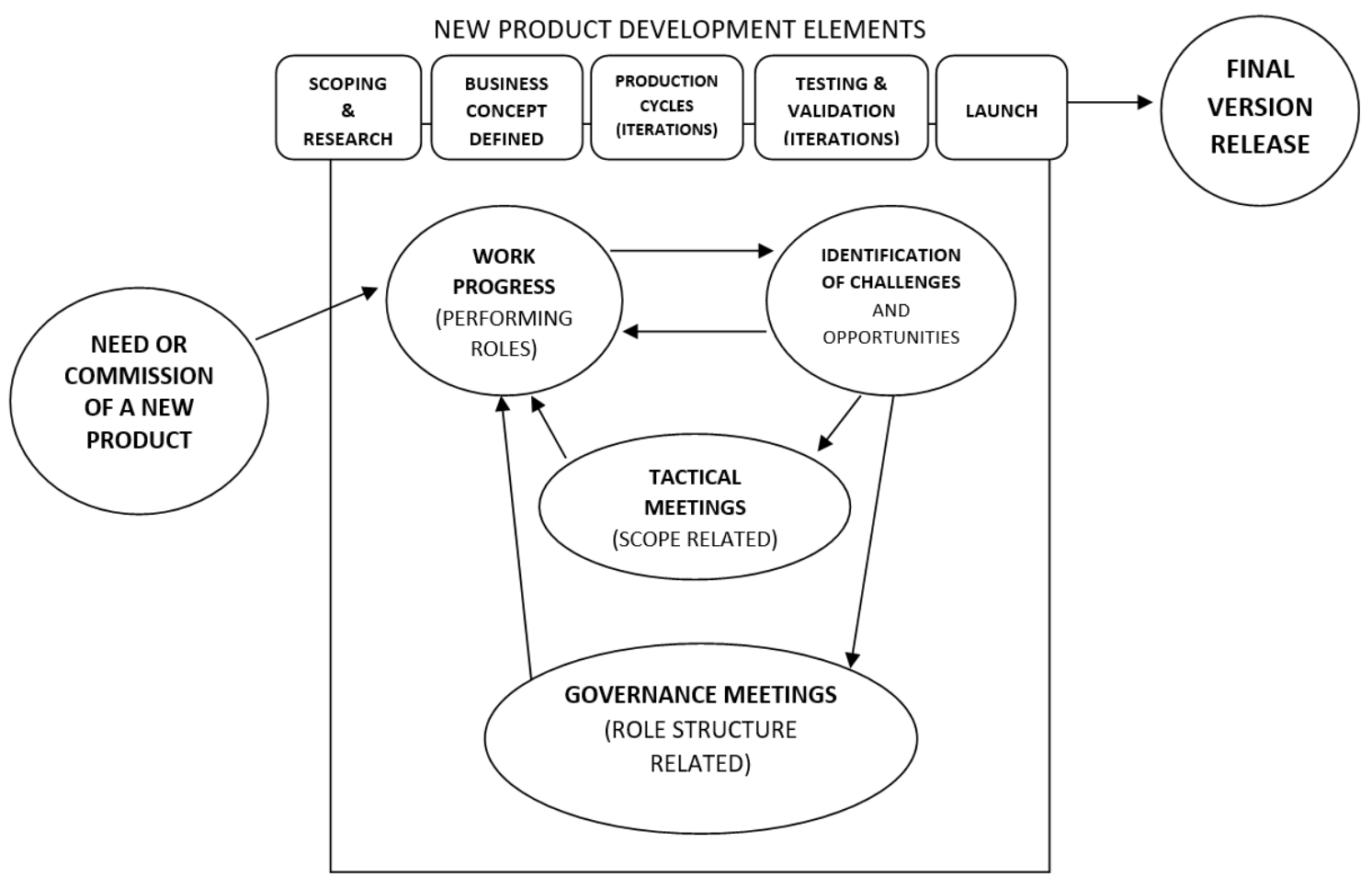

Figure 2. Work-flow of new product development process in holacracy. Source: own work based on Robertson B. J.: Holacracy: The New Management System for a Rapidly Changing World. Henry Holt and Company. 2015 \& Cooper G. R.: Agile-Stage-Gate Hybrids, Research-Technology Management, 59:1, 21-29. Cooper and Industrial Research Institute, 2016.

It should be noted that the model of a new product development used in Figure 2 is a hybrid model introduced by Robert G. Cooper, which integrates cyclic, iterative development process with the corresponding phases of traditional stage-gate new product development model (Cooper, 2016). In order to maintain the appropriate level of integration, transparency and communication within the circle structures, two types of meetings have to be organized management (governance) meetings and tactical-operational (operational) meetings. 
All meetings and events associated with holacracy may occur without any impediments during the whole new product development process. It seems that such meetings may have a positive impact on the risk analysis of an ongoing project or even on the new product idea generation and screening phases (scoping \& research). However, more research is required in this area to measure the exact level of aforementioned impact in specific industries. Both meetings play an important role in organizing the whole structure and roles of the individual employees (governance meetings), and allow for a quick review of tasks and projects implemented in the company (tactical meetings).

Each employee has a specific role and affiliation to a particular circle. However, the role of the employee may change if he or she acquires a number of new competencies or abilities. This phenomenon can be compared to classic role-playing games, where each hero has a certain character class, but can acquire different skills by training selected activities. Also, most employees have to train their skills or abilities under the guidance of senior-workers. This not only integrates the team more, but also instigates knowledge sharing in the enterprise.

\section{NPD projects executed in a holacracy-based organization - case study based on the example of IT companies developing software}

\subsection{Characteristics of surveyed enterprises}

A case study research was conducted in two Polish medium-sized IT companies. Selected companies agreed to conduct the research in March and April 2019. Both companies have been using holacracy for 3 years.

Company $\mathrm{X}$ has been operating on the market for 10 years and is a modern, dynamically evolving enterprise that develops software solutions and websites. It employs 42 full-time employees and several dozen freelancers hired on specific commissions. Also, it carries out various international IT projects.

Company $\mathrm{Y}$ has been operating on the market for 7 years and provides services in the field of video games development. It employs over 50 people and creates video games for such hardware platforms as personal computers, consoles and mobile devices.

\subsection{Description of research methods}

Empirical research conducted in the aforementioned business entities consisted of three following phases:

1) Research consisting in identifying the stages of new product development and characteristics of development work-flow (desk research, analysis of shared data and company documentation, conversations concerning the NPD process and organizational models used by enterprises). 
2) Research in the form of interviews with employees in order to identify key features of development teams operating in holacracy conditions. Analysis of advantages and disadvantages associated with each feature or attribute.

3) Research in the form of a questionnaire - comparative analysis of different approaches to new product development (Waterfall, Agile, Agile with Holacracy).

Research was conducted with participation of 23 employees from company $\mathrm{X}$ and 34 employees from company Y. The survey was anonymous. All respondents had at least 2 years' work-time experience in the company and had a position associated with new product development activities. In third phase of research, it should be noted that a total of 40 employees from both companies took part in the survey - because only this group of respondents had any experience with Agile methods used without holacracy.

\subsection{Analysis of new product development models in IT companies using holacracy}

Before describing a detailed analysis of new product development process in both IT companies, it should be explained how the general organization of development teams is being conducted and what communication systems are being used within companies, to be specific - which tools are used to ensure efficient flow of information.

In the case of the IT industry, the development of a new product is often based on a virtual project team. It can take different forms - sometimes software designers develop a whole new product online, in the cloud, and in other cases only a part of the work is developed online by specially appointed experts and professionals. Both Company X and Company $\mathrm{Y}$ use such solutions. Writing code in the cloud and exchanging individual product assets (packages of different types - source code, graphics, scripts, sound files) in online environment increases the productivity of development teams. Both companies have a fairly similar model of new product development (mainly based on the aforementioned hybrid model - combined with agile methods and NPD stages according to Robert G. Cooper), but their approach to the organization of development teams and their collaboration in a holacratic structure is slightly different.

Enterprises use a variety of online tools to support their workflow in virtual environments. These include: Slack virtual collaboration environment (instant messenger and file repository), Google Hangouts (instant messenger), Skype (phone/audio/video calls and conferences), Discord (voice and video-voice communication), Google Disk (file archive), Trello \& Google Sheets (used mainly for task planning and updating schedules), Dropbox (cloud file archive), and Messenger from Facebook - these tools are regarded as an absolute minimum (that is, are considered as a kind of standard) in both companies.

Both companies accept new product orders in quite similar way. New orders, commissioned by customers, are received and accepted by contractors, marketers, specially appointed product designers or sales and customer service specialists. Customers who order new products in the form of software, web portals or video games, make contact with one of the abovementioned employees (roles) and provide information about product's requirements - the main purpose 
and basic features of the product. Then, the product designer sets up a temporary working group consisting of employees and experts who have the capabilities and skills necessary to develop the product. It should be noted that in both companies (X and Y) - new product orders appear on public information boards of the company and in the cloud / communication systems, so that all employees and experts may join the project they are interested in. If there are no volunteers - external freelancers are sought or a product designer organizes a motivational meeting, encouraging employees to participate in the project and presents additional benefits associated with the specific product. Then, a meeting with the client is arranged, where all key features of the software and its utility values are discussed in detail. During the meeting, all important topics are discussed, such as technology that is going to be used, method of implementation or compatible hardware platforms on which the software shall work. At this particular moment the list of product functions is determined on the basis of user requirements (the so-called Product Backlog). This process is usually called Event Storming or defined as User Stories Mapping. Then, when team members already know what has to be done - the actual process of creating a new product begins. First objective is to code and compile the so-called pre-alpha version with basic functionalities of the final product. Everything is usually done in accordance with the Scrum method, which imposes the following rules:

- production cycles are divided into Sprints (lasting 2-4 weeks),

- Development Team organizes short daily meetings on a regular basis,

- each project has roles of Scrum Master, Product Owner and Development Team,

- Sprint Review and Sprint Retrospective meetings occur after every Sprint;

- the product is produced iteratively and is the sum of results of all individual increments (taking into account all changes of the scope of the project that may have appeared due to change of requirements and needs of the customer).

In both companies, product development decisions are made together in a collaborative and democratic manner. At the same time, there are situations where the key decisions are largely supervised by a specialist with the greatest experience in a specific field. In creative industries, important decisions are often left to experts who have been creating professional solutions for years, because they have a higher awareness of product's quality and valuable knowledge in the area of product development. When all product designers have more freedom in decision-making and the level of empowerment is high, then it may have a positive impact on the final value of the product. It also works the other way around - empowerment enhances the creativity and satisfaction levels of product designers. This is how temporary development teams are being created to develop a new product. Also, this is the point, where common elements between the two companies end. Their workflow organization and new product development models are slightly different. 


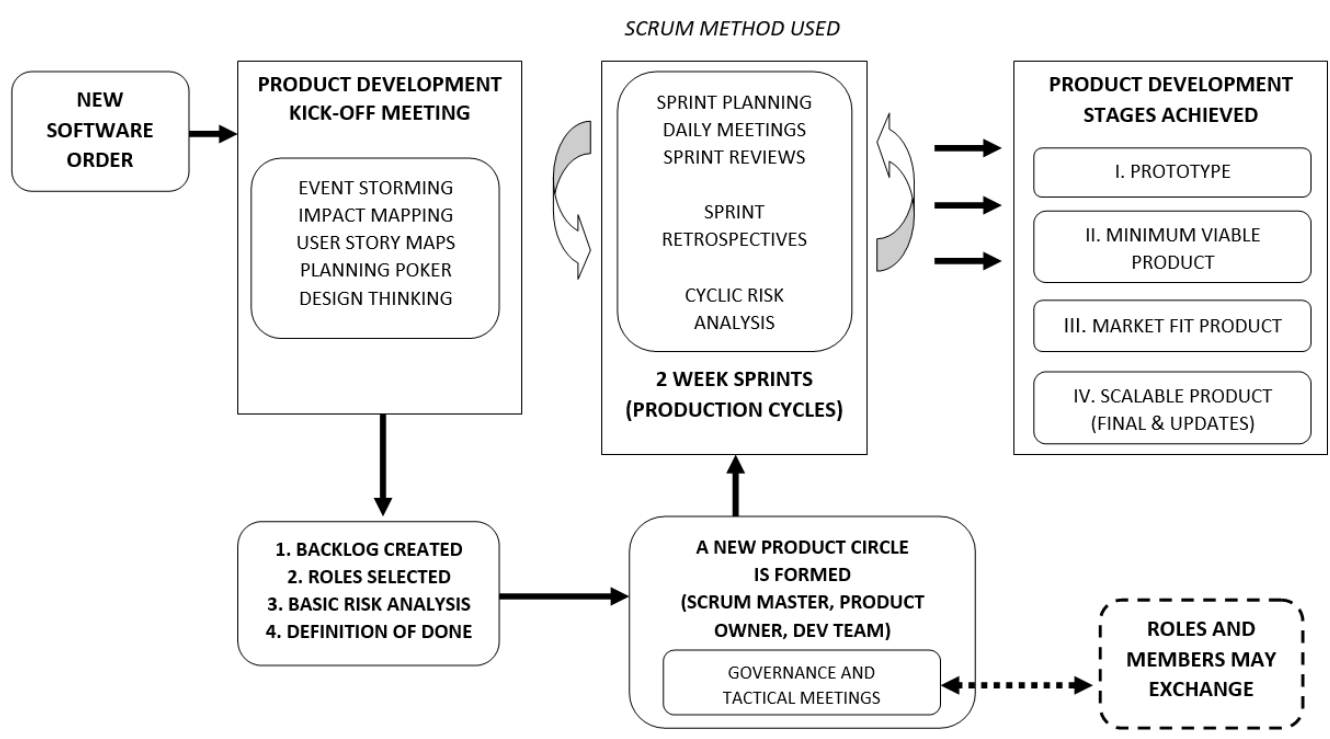

Figure 3. New product development model of enterprise X. Source: own work based on gathered research data.

The new product development model of company $\mathrm{X}$ is shown in figure 3 . As can be seen in the picture, the company has a number of its own solutions within the product development stages, which may be a result of their specialization in unique types of software. Websites, web platforms and professional software require frequent updates and patches - they must be constantly developed and improved. Therefore, access to the product backlog must be clear, fast, simple and effective. It all starts with a product development kick-off meeting. During it, the product backlog - list of features containing all functions of a new product is being created. Company $\mathrm{X}$ creates a product backlog based on such techniques as: event storming, impact or user story mapping, poker planning and design thinking. These methods allow for a better understanding of the essence of a new product, its sense of existence and usability from the user's perspective. Backlog is registered through Trello environment and GitHub version control system. Both pieces of software give full control over the implementation and status of the product development. Also, this is a key stage of defining when a product will be considered finished (definition of done), what requirements it must meet, as well as what potential risks and problems may arise during the development and implementation process. Once the product backlog is completed, all roles in product development team are being established.

Then the first sprint is started - a 2 week iteration. Usually one or two iterations are needed to create a prototype of a product, often referred to as a pre-alpha or alpha version. Later, with the subsequent iterations, more complex versions of the product are being created. An interesting aspect is the possibility of a dynamic transition of the individual members of development team between the development circles of new products. For example, one programmer would like to work on another business case for 2 iterations because he's an expert in a particular field and is convinced that his experience may add more value to the product. Such arrangements are made at one of the sprint summary meetings or can also be 
made at tactical meetings concerning projects and activities of various circles within the holacracy. This reveals the high flexibility of development teams and the overall selforganization of employees.

What is interesting, it should be noted that in enterprise $\mathrm{X}$ there are no project managers, and what is more - the employees explicitly state that there is no such thing as traditional project management in their company. By the word "project" they understand a temporarily implemented endeavor, which is managed by an integrated pool of human resources in this case self-organized engineers, programmers and specialists. Another interesting aspect is the approach to project's risk. Risk is managed by the whole development team together with Scrum Masters/Product Owners and it is being analyzed in an iterative manner. Preliminary risk analysis provides an additional protection and security.

NEW PRODUCT DEVELOPMENT MODEL OF ENTERPRISE Y

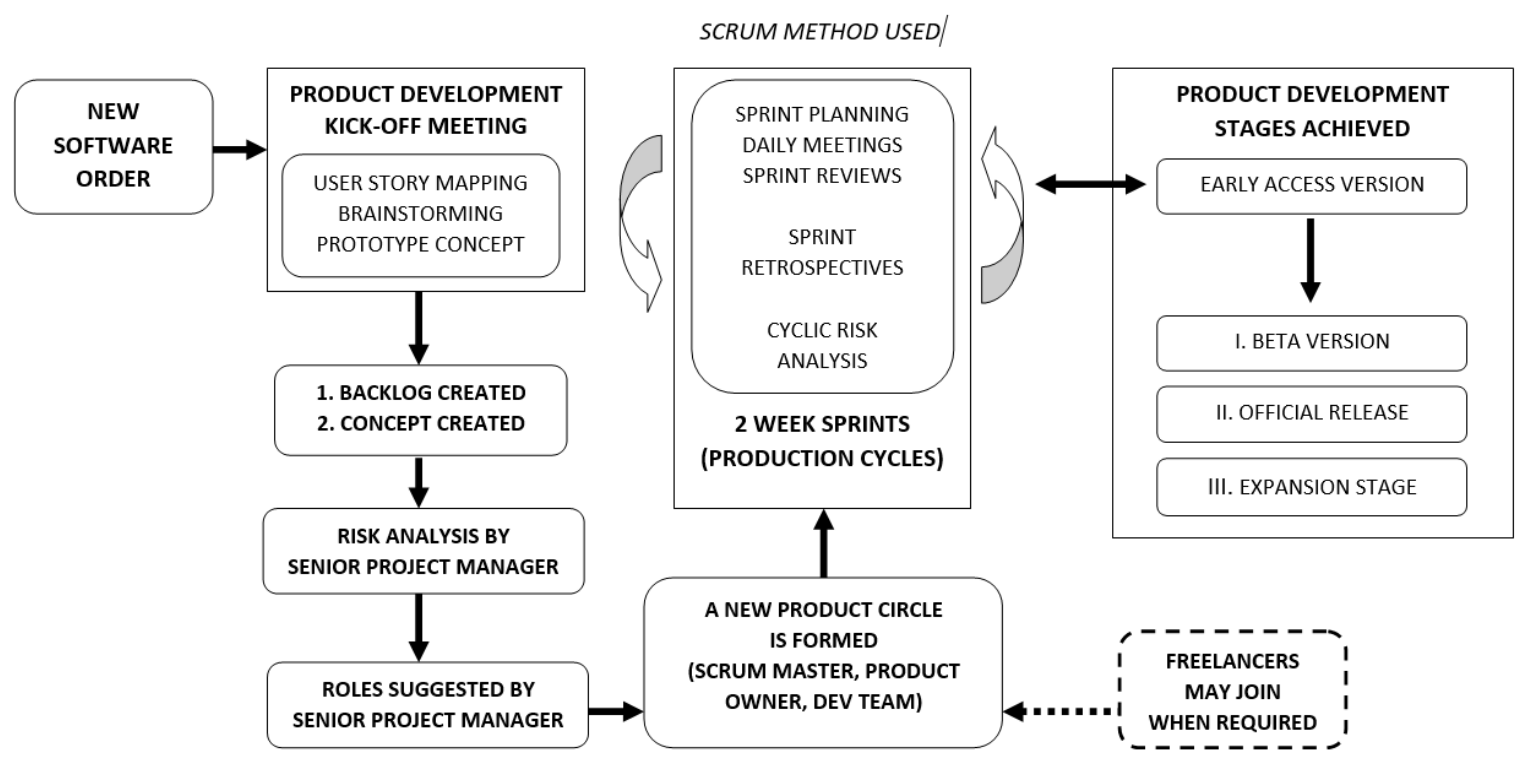

Figure 4. New product development model of enterprise Y. Source: own work based on gathered research data.

The most obvious difference of company $\mathrm{Y}$ is that it has a superior and experienced senior project manager who acts as a kind of coach for Scrum Masters and the entire team in difficult or troublesome situations. It should be noted that despite his formal function, his opinion and decisions are not binding or enforceable. The integrated opinion of the whole team is still important. In addition, the company uses fully-fledged project management and each project has an appropriate project documentation package (including schedule, resource sheet, a risk $\log$, budget file, which are being regularly updated in subsequent production cycles).

Another characteristic feature is the form of control over the project and team structure. As shown in Figure 3, company $\mathrm{X}$ uses an additional series of tactical and governing meetings during sprints and iterations, which are the result of the holacracy concept itself. Company $Y$ (Fig. 4) decided to separate the development team from the overall holacracy structure. 
It can therefore be concluded that company $\mathrm{Y}$ opted for some limited flexibility and greater project supervision by a senior project manager and a Scrum Master. In addition, freelancers and external experts can join the team if necessary. This is a slightly different approach compared to company $\mathrm{X}$, where development of know-how and human capital is more important.

The stage of commercialization and implementation of software on the market is also different. The company Y prefers to produce software in an early-access version, which is a version that can be purchased by end-users at an early stage of production as it already has some basic and key functionality (Liebert, 2017b). The users of a new product provide additional feedback so that subsequent iterations and production cycles are carried out in cooperation with a group of end users (and not, for example, with a single Product Owner representing a customer or user). After all objectives of early access have been completed, then the development of beta version begins. Later, the official version of the product is being released, after all user requirements have been met. Further stages of development include small software updates and larger expansion sets that will extend product's life cycle.

\subsection{Characteristics of development teams operating in a holacracy-based organization}

Development teams operating in IT companies, which base their structure on the concept of holacracy, have a number of unique features and characteristics. On the basis of interviews with employees of both companies, it was possible to determine the most important and essential features of teams working on new IT solutions in the holacratic environment. It should be noted, that each of these features may bring various benefits for the work-flow and product quality, and may also be a source of negative issues or problems, which in some cases may impede the work of programmers or other specialists. The characteristics of IT product development teams which operate within a holacracy have been presented in Table 1.

During the conducted research, many positive and negative aspects of particular features of development teams operating in holacracy were identified. As the table above shows, holacracy is certainly a modern, but very specific form of general organization of the company and its components. Implementation of holacracy in a company may require a sophisticated adjustment of organizational culture and technical resources. 
Table 1.

Features and key characteristics of holacratic development teams (in IT industry)

\begin{tabular}{|c|c|c|c|c|}
\hline Id. & $\begin{array}{c}\text { Characteristics and } \\
\text { features of } \\
\text { development teams } \\
\text { operating in the } \\
\text { holacracy }\end{array}$ & Description & Advantages and benefits & Disadvantages or problems \\
\hline 1. & $\begin{array}{l}\text { Purpose-driven } \\
\text { activities } \\
\text { (roles instead } \\
\text { traditional } \\
\text { employees) }\end{array}$ & $\begin{array}{l}\text { Instead of a typical hierarchical structure, democratic } \\
\text { collaborative approach is used, where each member } \\
\text { of the team selects and plays a certain role of } \\
\text { productive nature (related to technical or artistic } \\
\text { skills) or organizational nature (motivates and } \\
\text { supports the team). }\end{array}$ & $\begin{array}{l}\text { - No restrictions or excessive } \\
\text { supervision. } \\
\text { - Possibility of increasing knowledge } \\
\text { and triggering creative ideas. } \\
\text { - Flexible connections between } \\
\text { departments and units of the company. } \\
\text { - Empowerment. } \\
\text { - Self-organization. }\end{array}$ & $\begin{array}{l}\text { - Sometimes there is no clear division } \\
\text { of responsibilities. } \\
\text { - Managing risk may be a bit } \\
\text { difficult. } \\
\text { - The problem with establishing the } \\
\text { Definition of Done, i.e. the moment } \\
\text { of project completion. }\end{array}$ \\
\hline 2. & $\begin{array}{l}\text { Self-organization of } \\
\text { working teams }\end{array}$ & $\begin{array}{l}\text { Circle members can change their roles and assign } \\
\text { themselves to other projects as they see fit. } \\
\text { Employees can hand-off and pick-up roles at will. In } \\
\text { other words, they are free in the way they want to } \\
\text { achieve the goals described for those roles. }\end{array}$ & $\begin{array}{l}\text { - Optimal resource management. } \\
\text { - Quick start of product development } \\
\text { process. } \\
\text { - Increased innovativeness as a result of } \\
\text { extended knowledge sharing. }\end{array}$ & $\begin{array}{l}\text { - The problem of role rotation. } \\
\text { - Fast-paced changes - potential } \\
\text { chaos in the implementation of } \\
\text { several projects. }\end{array}$ \\
\hline 3. & $\begin{array}{l}\text { High transparency } \\
\text { and integrated } \\
\text { networks }\end{array}$ & $\begin{array}{l}\text { Employees operate in circles (many connected } \\
\text { circles may resemble a network), in which they } \\
\text { create a collaborative and transparent working } \\
\text { environment. Team members know what to do and } \\
\text { when to do it and can even play different roles in } \\
\text { different circles or sub-circles. Circle members have } \\
\text { a better understanding of company' values and its } \\
\text { products. }\end{array}$ & $\begin{array}{l}\text { - Trust and transparency. } \\
\text { - Knowledge of objectives and sense of } \\
\text { business activity. } \\
\text { - Better understanding of effects and } \\
\text { specific objectives of the project. } \\
\text { - Versatile roles. } \\
\text { - Better integration with team members. }\end{array}$ & $\begin{array}{l}\text { - Risk of losing the organization's } \\
\text { know-how or interception of } \\
\text { valuable data by temporary workers. } \\
\text { - Issues or conflicts caused by high } \\
\text { empowerment - many circle } \\
\text { members may start to act as a lead } \\
\text { manager. } \\
\text { - Problems with responsibility. }\end{array}$ \\
\hline 4. & $\begin{array}{c}\text { Mandatory } \\
\text { coaching and } \\
\text { effective knowledge } \\
\text { sharing } \\
\end{array}$ & $\begin{array}{l}\text { It is mandatory for new employees to be trained by } \\
\text { older colleagues. Over time, they also can acquire } \\
\text { coaching skills and train new members of the } \\
\text { company. }\end{array}$ & $\begin{array}{l}\text { - Mandatory knowledge sharing and } \\
\text { employee development. } \\
\text { - Integration with the team. }\end{array}$ & $\begin{array}{l}\text { - Requires new employees to adapt to } \\
\text { a specific organizational culture. }\end{array}$ \\
\hline
\end{tabular}


Cont. Table 1.

\begin{tabular}{|c|c|c|c|c|}
\hline 5. & $\begin{array}{c}\text { Swift } \\
\text { communication } \\
\text { and use of modern } \\
\text { IT tools }\end{array}$ & $\begin{array}{l}\text { Organization of tactical and governance meetings. } \\
\text { Fast and effective communication channels. } \\
\text { Availability of IT tools which ensure swift } \\
\text { communication within the team, especially in virtual } \\
\text { environments. Availability of IT tools which can be } \\
\text { used to properly set up a virtual workspace. }\end{array}$ & $\begin{array}{l}\text { - } \text { Fast and effective communication. } \\
\text { - Virtual development teams. } \\
\text { - Optimal flow of information within the } \\
\text { workspace framework - feedback } \\
\text { within individual units of the } \\
\text { development team. }\end{array}$ & $\begin{array}{l}\text { - In the case of virtual teams, the risk } \\
\text { of failure - Internet or power outage } \\
\text { - can disrupt cooperation and cause } \\
\text { unexpected problems. } \\
\text { - The problem of cyber security. }\end{array}$ \\
\hline 6. & $\begin{array}{c}\text { Agile project } \\
\text { management and } \\
\text { high flexibility }\end{array}$ & $\begin{array}{l}\text { Use of agile team management methods: Scrum, } \\
\text { Srumban, etc. Team uses Scrum roles, that is - } \\
\text { Scrum Master, Product Owner, Development Team. } \\
\text { All Scrum artifacts, events and roles are maintained } \\
\text { properly. Permanent cooperation with the user/ } \\
\text { customer has to be maintained. }\end{array}$ & $\begin{array}{l}\text { Quick response to potential customer } \\
\text { needs and the ability to change the } \\
\text { scope of the project. } \\
\text { Optimal adaptation to every type of } \\
\text { project in order to meet customer } \\
\text { requirements, increase product's } \\
\text { quality and add more value. }\end{array}$ & $\begin{array}{l}\text { Implementing agile management } \\
\text { and agile methods such as Scrum is } \\
\text { complicated and requires a specific } \\
\text { organizational culture. }\end{array}$ \\
\hline 7. & $\begin{array}{l}\text { Empowerment and } \\
\text { authority in } \\
\text { decision making } \\
\text { (democratic change } \\
\text { management) }\end{array}$ & $\begin{array}{l}\text { The changes are discussed in collaborative way and } \\
\text { everyone has authority to implement a change in the } \\
\text { project where additive production cycles take place } \\
\text { (incremental, continuous addition of new functions } \\
\text { and elements). In some cases, the product may be } \\
\text { supervised by an expert with the greatest experience } \\
\text { in a specific field. }\end{array}$ & $\begin{array}{l}\text { - No changes are being imposed from } \\
\text { above. } \\
\text { Every employee has an opportunity to } \\
\text { express individual opinion about a } \\
\text { certain matter. } \\
\text { - A sense of co-authorship and high self- } \\
\text { esteem. }\end{array}$ & $\begin{array}{l}\text { Potential conflicts and } \\
\text { misunderstandings in two distinct } \\
\text { visions within the product } \\
\text { development. } \\
\text { - If a specific product is run by } \\
\text { an expert, his/her sudden lack may } \\
\text { disrupt the development process due } \\
\text { to random reasons. }\end{array}$ \\
\hline 8. & $\begin{array}{l}\text { Self-development } \\
\text { and additional } \\
\text { benefits }\end{array}$ & $\begin{array}{l}\text { Unlimited development and training opportunities } \\
\text { (workshops, training courses) financed by the } \\
\text { company. Special integrating tours and trips - } \\
\text { possibility to work remotely. The possibility of } \\
\text { taking home office on demand without any questions } \\
\text { asked (virtual office). Unique, user-friendly work- } \\
\text { spaces. }\end{array}$ & $\begin{array}{l}\text { - Possibility to broaden a skillset. } \\
\text { - } \text { Aork is combined with leisure. } \\
\text { - A sense of integration and security in } \\
\text { the company. } \\
\text { - Modern working environment that } \\
\text { triggers creativity. }\end{array}$ & $\begin{array}{l}\text { Unique work culture - } \\
\text { new employees, who don't have any } \\
\text { experience with holacracy, may } \\
\text { encounter serious problems to adapt } \\
\text { to such unique working conditions. }\end{array}$ \\
\hline
\end{tabular}

Source: own work based on the gathered research data. 


\subsection{Comparison of Waterfall, Agile and Agile with Holacracy from the perspective of new product development and project management}

The last stage of the research was a comparative analysis of approaches to new product development from the perspective of project management. In order to prepare such comparison, developers of both companies were asked to evaluate the potential of every project element in accordance to a selected product development method (Table 2).

Table 2.

Comparison of different approaches in NPD, project and team management in IT industry

\begin{tabular}{|c|c|c|c|}
\hline \multirow[b]{2}{*}{$\begin{array}{l}\text { Element of the new } \\
\text { product development } \\
\text { project }\end{array}$} & \multicolumn{3}{|c|}{ Methods and approach to product development and development teams } \\
\hline & $\begin{array}{c}\text { Traditional Project } \\
\text { Management } \\
\text { (Waterfall) } \\
\end{array}$ & $\begin{array}{c}\text { Agile Project } \\
\text { Management } \\
\text { (APM, Scrum) } \\
\end{array}$ & $\begin{array}{c}\text { Agile Project } \\
\text { Management (APM, } \\
\text { Scrum) with Holacracy }\end{array}$ \\
\hline $\begin{array}{c}\text { Conditions for } \\
\text { implementing product } \\
\text { innovations } \\
\end{array}$ & $\begin{array}{c}\text { Low or Very } \\
\text { constrained }\end{array}$ & High & Very High \\
\hline Project's goal & Fixed (Permanent) & Dynamic & Dynamic \\
\hline Planning time & Long & Short & Very short \\
\hline Resource cost & High & Medium & Medium or Low \\
\hline Product quality & Medium & High & Very High \\
\hline Project's scope & Fixed (Permanent) & $\begin{array}{l}\text { Variable and adjusted } \\
\text { to user's requirements }\end{array}$ & $\begin{array}{c}\text { Variable and adjusted to } \\
\text { user's requirements }\end{array}$ \\
\hline Duration of the project & Medium or Long & Medium or Short & Short or Very Short \\
\hline
\end{tabular}

Source: Own work based on the research data.

The respondents' task was to characterize and score following project elements: conditions for implementing product innovations, project's goal, planning time, resource cost, product quality, project's scope, duration of the project. Each element (area) of the project had a five-stage evaluation scale with values from -2 to +2 , where -2 was the worst result and +2 the best one (Likert scale). As shown in Table 2, Agile Project Management enables development teams to adjust project's scope and allows them to search for more innovative solutions that may improve the developed product. This has a positive impact on the final value of the product. Additional advantages of Agile methods are definitely the much shorter project durations and faster delivery of a specific solution. Waterfall approach looks obsolete and slow in comparison to APM. However, the most distinctive method is Agile Project Management combined with Holacracy, where conditions for implementing innovations are very high, project planning time and project duration are very short, and the quality of final product can reach even higher levels. Agile Project Management with Holacracy is a modern approach that makes perfect use of company resources and may have a significant impact on company's competitiveness. 


\section{Conclusion}

Holacracy is a modern approach to managing the product development team, managing an organization as a whole and thus managing the development of a new product. The article presents the characteristics of IT development teams working on new products in holacracy. Flexibility of unique structures in form of roles and circles, as well as lack of high level of supervision due to the lack of hierarchy, have a positive impact on the value of the final product. If a certain company manages to successfully implement holacracy and agile management methods, it will offer extraordinary working conditions in dynamic environments, where experts and employees can become self-organized and empowered. Such company members may fulfill their needs of belonging and self-development in a much easier way than in traditional corporations. However, it should be noted that such solutions require a specific organizational culture, highly developed internal systems and appropriate technical resources. A rather small number of enterprises will be able to transform from a corporation managed by procedures into a self-organizing organism.

It is worth considering if there are any disadvantages or drawbacks of such a modern approach. An organization cannot be deprived of structure or hierarchy, even in such a modern concept as holacracy - there are some structures and superior roles (lead roles) which, although they have a different scope of managing authority, can still have a significant impact on particular departments or working groups. Processes of risk identification and analysis, which are being performed in a cyclical manner, can be challenging when several projects are executed in the same time. Role shifting and rotations during swift role exchanges may cause severe issues. Other doubts may arise when we refer to the responsibility for particular projects or products. Although roles are clearly assigned to certain tasks, some issues may occur when a task is not properly defined or performed (and has been performed by several people to varying degrees). However, proper adaptation to organizational culture and cyber-security are the most controversial issues. Most people working in classic top-down corporations are unlikely to find themselves in a modern, holacratic environment full of freedom and self-organization. The habit of receiving orders from higher-level managers may be too strong in this case. In addition, excessive trust and transparency may cause a threat. A large amount of sensitive company data is often widely shared to all circle members when needed, which is a positive practice to complete project tasks but it's quite risky. For example, one of part-time employees may decide to illegally intercept a certain amount of valuable assets after he (or she) has ended his (or her) collaboration with a company. Another issue is the empowerment of processes or governing rules instead of people - Holacracy Constitution has 38 pages of principles and rules which may seem more complicated than establishing a typical linear structure with a simple hierarchy. Learning curve of holacracy seems to be quite high. 
The phenomenon of holacracy is interesting from a scientific point of view and certainly requires more research in the area of business practice. For years, companies have been struggling to create a perfect environment that enhances creativity and pro-innovative culture. There are good chances that in a dozen or so years' time the holacracy will be one of the basic organizational structures of companies in creative industries, especially in the IT industry.

\section{References}

1. Cooper, G.R. (2016). Agile-Stage-Gate Hybrids. Research-Technology Management, 59, 1, 21-29. Cooper and Industrial Research Institute.

2. Coughlan, T., College, M. (2016). Structured for Success: How the Structure of Today's Professional Organizations Are Changing. Journal of Management and Innovation, 2(1), Spring.

3. Danielak, W. (2010). Elementy kapitału relacyjnego oddziałujące na konkurencyjność małych i średnich przedsiębiorstw. In: M. Matejun (ed.), Wyzwania i perspektywy zarzadzania $w$ matych i średnich przedsiębiorstwach. Warszawa: C.H. Beck.

4. Frederic, L. (2014). Reinventing Organizations. Nelson Parker.

5. Ellis, G.F.R. (2016). Agile Project Management: Scrum, eXtreme Programming, and Scrumban. Project Management in Product Development. Wyd. Butterworth-Heinemann.

6. Gopalakrishnan, S., and Damanpour, F. (1997). A review of innovation research in economics, sociology and technology management. Omega: The International Journal of Management Science, 25, 1.

7. Griffin, R.W. (1998). Podstawy Zarzadzania Organizacjami. Warszawa: PWN.

8. Highsmith, J. (2005). APM: Agile Project Management. Jak tworzyć innowacyjne produkty. Warszawa: Wyd. Mikom.

9. Holacracy Quickstart Guide v. 2.3a - available online: http://www.holacracy.org/wpcontent/uploads/2015/05/holacracy_quickstart_guide_v2.3a.pdf, 03.03.2019.

10. Januszak, W., and Januszak, K., and Prozorowicz, M., and Świadek, A., and Wiśniewska, J. (2002). Determinanty innowacyjności przedsiębiorstw. Wydawnictwo Naukowe Uniwersytetu Szczecińskiego.

11. Kozina, A., Pieczonka, A. (2018). "Turkusowe podejście" do zarządzania konfliktami organizacyjnymi. Marketing i Zarzadzanie, 1(51).

12. Liebert, F. (2017). Usługa wczesnego dostępu do produktu w dystrybucji cyfrowej z perspektywy producenta na przykładzie platformy internetowej Steam. Zeszyty Naukowe Politechniki Ślaskiej, seria Organizacja i Zarzadzanie, 103, Gliwice. 
13. Liebert, F. (2017). Zarządzanie projektami w przedsiębiorstwach branży IT - studium literaturowe. Zeszyty Naukowe Politechniki Ślaskiej, Seria Organizacja i Zarządzanie, 101, Gliwice.

14. Liebert, F. (2018). Atrybuty innowacyjnego produktu informatycznego w postaci oprogramowania. Zeszyty Naukowe Politechniki Śląskiej, Seria Organizacja i Zarządzanie, 121, Gliwice.

15. Official webpage of HolacracyOne: https://www.holacracy.org/constitution, $3^{\text {rd }}$ of March 2019.

16. Olesiński, Z. (2018). Samozarządzanie jako metoda zarządzania zespołami projektowymi. Zeszyty Naukowe Wydziatu Informatycznych Technik Zarządzania Wyższej Szkoty Informatyki Stosowanej i Zarządzania „, Współczesne Problemy Zarzadzania”, 1.

17. Powichrowska, B. (2018). Od zarządzania wiedzą do zarządzania w kolorze turkusu. Przedsiębiorstwo \& Finanse, 1, Wyższa Szkoła Finansów i Zarządzania w Białymstoku.

18. Robertson, B.J. (2015). Holacracy: The New Management System for a Rapidly Changing World. Henry Holt and Company.

19. Robertson, B.J. (2015). Holacracy: The Revolutionary Management System that Abolishes Hierarchy. UK: Penguin.

20. Stabryła, A., Małkus, T. (2012). Strategie rozwoju organizacji. Encyklopedia Zarządzania, Kraków.

21. Tomaszycka-Hopej, M., Hopej, M. (2018). Struktury organizacyjne turkusowych organizacji. Zeszyty Naukowe Politechniki Ślaskiej, seria Organizacji i Zarządzanie, 130. Politechnika Śląska.

22. Van de Kamp, P. (2014). Holacracy - A Radical Approach to Organizational Design. ELEMENTS OF THE SOFTWARE DEVELOPMENT PROCESS - Influences on Project Success and Failure, Chapter: 2, Publisher: University of Amsterdam.

23. Ziębicki, B. (2017). Organizacje bez "szefów" - współczesna moda czy nowy paradygmat zarządzania? Humanizacja pracy, 4(290) (L). Szkoła Wyższa im. Pawła Włodkowica w Płocku. 